\title{
Being Honest About Tenure in the United States: The Need for Tenure System Reform within Institutions of Higher Education
}

\author{
Dr. Arthur Gross-Schaefer ${ }^{1}$, Sona Gala ${ }^{2}$, Jillian Jaccard ${ }^{3}$, Luke Vetter ${ }^{4}$ \\ ${ }^{1}$ College of Business Administration, Professor of Business Law and Ethics, Loyola Marymount University, Los Angeles, \\ CA, USA. \\ ${ }^{2}$ College of Business Administration, Loyola Marymount University, Los Angeles, CA, USA. \\ ${ }^{3}$ College of Business Administration, Lecturer Business Law, Loyola Marymount University, Los Angeles, CA, USA. \\ ${ }^{4}$ College of Business Administration, Research Assistant, Loyola Marymount University, Los Angeles, CA, USA.
}

Correspondence: Sona Gala, Lecturer, Department of Marketing and Business Law, Loyola Marymount University, Los Angeles, CA, Attorney at Law, Orange County, CA, USA.

Received: April 21, 2015

doi:10.11114/ijsss.v3i4.827
Accepted: May 6, $2015 \quad$ Available online: May 19, 2015

URL: http://dx.doi.org/10.11114/ijsss.v3i4.827

\begin{abstract}
This paper examines whether the tenure system at the university level today is in need of reform. To answer this complex and highly charged question, the authors begin by first tracing the history of tenure, from its inception in Europe to its emergence in the United States. Next, the paper examines the significant role played by the American Association of University Professors (AAUP) in defining tenure at the collegiate level today. The article then moves into an analysis of the current state of tenure through the review of key aspects of the university tenure process. The authors conclude with observations and suggestions for potential reform of the tenure system.
\end{abstract}

Keywords: tenure, history of tenure, university, American Association of University Professors, university system, reform.

\section{Introduction}

Is tenure at the university level in need of reform? This complex and highly charged question cannot be answered without a comprehensive understanding of the origins of tenure and its historical development in the United States education system. Simply stated, it is critical to understand the experience of medieval scholars regarding the oppression they faced from outside groups including the church, government, and academic administrators. These multifaceted manifestations of outside interference were significant factors in the initial development of tenure in medieval times, and the influence of these origins continues to be viewed as a critical foundation for the contemporary continuation of the tenure system.

Accordingly, this paper begins by tracing the history of tenure, from its inception in Europe to its emergence in the United States. The paper examines the significant role played by the American Association of University Professors (AAUP) in defining tenure at the collegiate level today. It then moves into an analysis of the current state of tenure through the review of key aspects of the university tenure process. The article concludes with observations and suggestions regarding tenure. It is the authors' sincere belief that this article will help to engage those interested in the quality of higher education in a robust and nuanced discussion on the need for tenure reform.

\section{History of Tenure}

\subsection{Academic Tenure in Europe}

Academic tenure in the United States hails from European universities that had their origins in the medieval Catholic setting. Higher education in Europe generally took place for hundreds of years in cathedral and monastic schools, under the watchful eye of the Church hierarchy. As Europe urbanized, the clergy clung to their academic roots and attempted to safeguard their historic influence within the higher education sector. Theologians were degreed masters who were direct products of the medieval university. During the Middle Ages, scholars were offered special benefits, including protection and compensation for injuries (Metzger, 1973).

By the Thirteenth century, the subject of tenure had become both a heated political and religious issue. Chancellors for 
various institutions were in control of awarding teaching licenses. Their power to award or revoke academic status forced scholars to swear their allegiance to the chancellor. Believing this was an abuse of power, the scholars appealed to Rome and won. The resulting papal decree stated that a chancellor could only award licentia docendi (Jeffrey \& Manganiello, 1998) to individuals certified by the faculty, and that an oath of obedience must be sworn to the university, rather than to the particular chancellor. This decree also outlawed the chancellor's power of revocation (McCormick, 1988).

While the point of the decree was to keep one's performance as a scholar separate from assumed external authority in terms of faculty qualification issues, history demonstrated that the papal decree was much more effective on paper than in practice. In Paris, for example, bishops had the power to try scholarly offenders of canon law and punish them accordingly. Scholars initiated resistance to the bishops' actions by expanding the power of competing courts: the court of the conservator apostolic, which protected papal interests, and the court of academic rector, which represented the university (McNair, 1898).

In 1219, bishops were forbidden to excommunicate a teacher or a student without the Pope's approval (Wiseman, 1898). During this time, tenure was essentially characterized by admission to a "body" which had legal power, governmental authority, and a degree of independent sovereignty. These "bodies" were known as quasi-autonomous guilds composed of masters and scholars (Brubacher \& Rudy, 1997). The guilds operated on a fine line between seeking protection from the Church or Monarchy, and combating their authority as a means to maintain their independence (Dowley, 1989). Despite battles with church hierarchy, admission to the guild was achieved through demonstration of specific qualifications, or having certain academic credentials, and could only be revoked by the guild itself (Metzger, 1973). Walter Metzger states, "At bottom, tenure as a privilege was a declaration of opposition to any academic sanction from any nonacademic source" (Metzger, 1973). The guilds did have their disadvantages, though. Members had to conform to rules made by the guild, which often governed nonacademic aspects of members' lives that reached well beyond the scope of scholasticism. Personal independence was effectively sacrificed to gain collective power (Metzger, 1973).

During the Reformation in Europe, the power of faculty tenure was significantly diminished. While papal supremacy and control disappeared, monarchies financial support became the critical source of funds for scholars and universities. Professors became heavily reliant upon the state for monetary support, and the distinction between "inside" and "outside," the classic tenurial was destroyed. The King of France went so far as to set up the Parliament of Paris, which was a supreme tribunal of universities designed to allow the law of the state to reign supreme (Metzger, 1973). Thus, while scholars appeared to gain their rightful autonomy, they still remained heavily reliant upon the state for funding.

By the $19^{\text {th }}$ century, academic autonomy was in fact relegated to next to nothing. Scholars were required to obtain approval from higher powers in the government before acting (Metzger, 1973). In England, royalty was placed in charge of universities. The royals readily exercised their power by placing favorites in high academic positions, while eliminating those who held differing opinions (Metzger, 1973).

\subsection{Academic Tenure in the United States}

Shifting our focus toward North America, academic tenure had become an issue even before the Declaration of Independence was signed. By the early 1700s, the concept of tenure was being discussed and defined in the universities of the thirteen colonies that would soon be called the United States (Cameron, 2010).

Harvard University was a pioneer in developing the meaning and implications of tenure in the new America. Tenure was originally set up as a system based on an indefinite contractual relationship between the institution and the scholar (Cameron, 2010). Harvard then began to establish term limits allowing for only short-term professorial appointments (Metzger, 1973). Josiah Quincy, the president of Harvard, stated:

"The corporation began to perceive the inconvenience (of appointing) very young men without limitation of time, who, if they possessed good talents would speedily be induced to resign and (who) if they did not possess the ability to become eminent in a profession, would be fixed on the college for life" (Quincy, 1840).

In Mr. Quincy's opinion, if Harvard allowed indefinite tenure, the university would be stuck with inferior professors forever, while superior ones would resign and go to universities where they would receive better benefits. The purpose of the limited appointment was "to excite tutors from time to time to greater care and fidelity in their work" (Peirce, 1833). Job insecurity, it was thought, would be a deterrent for poor performance and thus inspire greater effort.

From the late colonial period on, the "protective potency of indefinite tenure declined" (Metzger, 1973). This can be observed by comparing Yale's tenure policies in the 1700's with the changes that developed in the 1800's. In 1701 Yale University's constitution adopted the position of a trustee, who believed a professor could only be dismissed if they displayed a lack of good behavior (Brubacher \& Rudy, 1997). In 1745, Yale moved away from their initial position on tenure and adopted a new document, giving the university discretionary power to combat theological sin. Professors could now be dismissed for cause, which included any misdemeanor, unfaithfulness, default, or incapacity (Baldwin, 1841). 
Unfortunately for the professors at Yale, Congregational clergy solely occupied the university's governing board (Brubacher \& Rudy, 1997). By the end of the Civil War in 1865, the standards at Yale had become even more lenient, allowing for professors at Yale to be dismissed for "inadequate performance of duty and misconduct" (Schuster \& Finkelstein, 2006). Rules at institutions of higher learning throughout the United States were unraveling and it was becoming easier for clergy-run university boards to fire professors. Hiring requirements were eliminated and the board could now fire anyone for virtually any reason (Schuster \& Finkelstein, 2006).

Even more surprising, the requirement of a trial to fire someone was dropped in the early $19^{\text {th }}$ century because it was such a painful and costly ordeal. Between 1860 and 1914, a study of eighty-eight dismissals and four near dismissals found that only six were preceded by a proper termination hearing (Metzger, 1973). Tenure offered very little protection for unwanted professors and institutions simply did not want to deal with trials and hearings.

One of the factors that contributed to the decline in the power of tenure was the decline of religious power in American universities; wealthy secular donors replaced religious leaders as trustees. By the beginning of the $20^{\text {th }}$ century, two-thirds of trustees at universities were businessmen (Brubacher \& Rudy, 1997). With the evolution of academic research, wealthy trustees only funded professors who had similar views, especially economic and political. Because universities were so desperate for funding, many professors with controversial views were dismissed, especially if their views differed from those held by members of the board or donors (Brown, 1997).

Professors felt that they needed tenure to create a fair balance of power between the board and the faculty. They wanted to be able to speak in public as normal citizens without looming punishment or professional repercussions. A professor's only defense was his right to challenge the administration in court, but only a small number exercised that right. Those few cases proved unsuccessful; the court stated that professors could be fired without a formal hearing or a show of cause (Metzger, 1973). Professors tried utilizing employment law tactics in the courtroom, but courts were extremely hesitant to order reinstatement through the equity tool of specific performance (Metzger, 1973). An unwritten rule developed: professors would not sue the president. The professor did not want to sacrifice his relationship with the president, not only for personal reasons, but also because the president had nearly unlimited disciplinary power (Metzger, 1973).

In 1894, a Wisconsin state court case, Gillan v. Board of Regents of Normal Schools, declared that the Board of Regents did not have to offer a pre-dismissal hearing because the trial and the publicity would just simply hurt the school (Gillian v. Board of Regents of Normal Schools, 1894). The power of the pleasure principle, which would be defined a few years later, was given to the Board in order to facilitate a silent removal of faculty members. This power gave, in effect, the Board of Regents absolute control over employment.

In 1898, the pleasure principle was defined in the case People Ex Rel Kelsey v. New York Medical School (People Ex Rel Kelsey v. New York Medical School, 1898). The principle delineated that if a professor may leave at his pleasure, then the board may terminate his employment status at its pleasure (Metzger, 1973). Along similar lines a year later, a ruling in an Arizona state court, DeVol v Board of Regents of University of Arizona, became law. The DeVol court took the position that a promise of appointment for a specific term was legally unenforceable because it was in direct violation of the interests of the institution (DeVol v. Board of Regents of University of Arizona, 1899). Time commitments could not be ingrained in a contract because such a contract could potentially restrict a university from acting in its best interest (DeVol v. Board of Regents of University of Arizona, 1899).

As predicted, without unlimited terms, the best professors had no interest in teaching at Harvard. Desperate to attract and keep high scholars in the late $19^{\text {th }}$ century, Harvard offered lifelong positions to two sought-after European professors. Without the lifelong appointments, these top quality professors would not have been attracted to a teaching job at Harvard (Unger, 2007). Soon the "up or out rule" was applied to the university system (Siow, 1998). There was a hierarchy of ranks set up for a professor to move through, with the lower ranks serving as proving grounds. Once a professor proved himself, he could move "out" of the lower ranks and "up" into the higher ranks. While the "out" was supposed to limit time spent in the lower ranks, this theory was never put into practice. Because no specific time limits were set with respect to remaining in the lower ranks, professors stagnated at the lower level and never moved "up or out" (Siow, 1998).

The other $19^{\text {th }}$ century method, used primarily in state schools, gave each professor a one-year term. Good professors would get a renewed contract at the end of the year. University presidents did not like this method because in the spring, professors were distracted from teaching to instead focus on keeping their jobs. Presidents came to prefer contracts for lower ranked employees and indefinite appointments for higher ranked ones (Metzger, 1973). The trend moved toward indefinite appointment.

A 1910 survey of 22 universities demonstrated that none of these universities made faculty members renew contracts annually, except for those ranked at instructor (Peterson, 2007). In contrast, a 1914 survey of 43 land grant colleges revealed that only two appointed teachers did not have to renew annually (Metzger, 1973). American professors were now expecting the treatment the Germans received with respect to tenure. At higher levels, professors in Germany received 
indefinite appointment except for "grave dereliction" (Flood, 2012). At lower levels, contract renewals were based on proficiency. To dismiss a professor from the higher levels, a judicial body had to bring the case against the professor, while at lower levels, the professor had to defend himself (Flood, 2012).

One of the biggest steps in the development of academic tenure as it is seen in the United States today, was the formation of the American Association of University Professors (AAUP) in January 1915 (Pollitt \& Kurland, 1998). At first, the AAUP was centered on two proposals. The first was to create tenure rules to favor professors, and have them standardized nationally. The second proposal asked for fellow professors to be judges in all dismissal cases (White, 2000). Ironically, the majority of the people who signed these proposals were extremely talented professors, who were the least in need of new tenure rules (Pollitt \& Kurland, 1998).

The writer of the AAUP proposals, Arthur Lovejoy, was an admired and accomplished professor at Johns Hopkins University. Some years earlier, in 1900, Lovejoy had been a co-worker of Edward Ross at Stanford. Ross was then in the middle of one of the biggest academic freedom cases of the time (Pollitt \& Kurland, 1998). He was fired because he had conflicting views with the university's benefactor, Jane Lathrop Stanford, who had complete control over the board of trustees and the whole university. Stanford's opposition to Ross originated years earlier in 1896 when Ross expressed political views that Stanford did not like (Mohr, 1970). The comments that led to Ross's dismissal involved his opposition to bringing Asian labor into the United States, as well as his belief in public ownership of municipal utilities. Neither of these views were expressed in a classroom setting, but rather, were expressed during off-campus speeches (Mohr, 1970).

The public reacted strongly to the firing of Ross because they feared that such constraints would halt the advancement of science (Mohr, 1970). In a personal collection of over 500 articles about the incident, Ross found that 29 out of every 30 articles written were in his favor. He also had strong support from the labor unions and many politicians (Mohr, 1970).

The president of the university, David Starr Jordan, was originally a strong supporter of Ross, but in order to save the university, he had to side with Stanford. Starr proclaimed that Ross was fired for his own shortcomings (Mohr, 1970). The president announced this specific reason for termination because he needed to attract top social scientists. Admitting that social scientists should watch what they say would not be conducive to his recruitment efforts (Metzger, 1973).

Lovejoy believed that removals were often based on reasons of political pressure rather than caused by poor performance or impropriety. His suspicions were heavily based on the fact that Ross was denied a trial and a hearing (Metzger, 1973). Lovejoy devised two solutions; the first would require turning the dismissal process into a judicial process set up to catch improper removals, and the second would require that an impartial investigation take place (Metzger, 1973).

The incident at Stanford impassioned the academic community by illuminating that a drastic change to the current system was necessary to protect academic rights and personal freedom of expression. That encouraged Arthur Lovejoy, along with seventeen other faculty members at Johns Hopkins University, where Lovejoy was teaching following his resignation from Stanford, to send a letter to full professors at nine other prestigious universities. This coordinated effort resulted in the founding of the AAUP. The letter asked these individuals to help form an association of professors that encompassed all fields (Pollitt \& Kurland, 1998).

Prior to issuing their first report, the association conducted an investigation of five universities that were chosen based on incidences of professors' rights violations. The American Economic Association, American Political Science Association, and American Sociological Association already had committees working together to study academic freedom and tenure. These groups, along with the AAUP's newly formed Committee on Academic Freedom and Tenure, were under intense pressure to investigate complaints at these five universities quickly because the number of instances in which professors felt they were treated unfairly was growing rapidly (Pollitt \& Kurland, 1998). The first subject of investigation was the University of Utah, which Arthur Lovejoy personally visited. He found that all professors were appointed for one-year terms, and they could be terminated at the will of the board. There was no legal structure or standard regarding termination or reappointment. Everything was done on a case-by-case basis, which the president and the board oversaw. Lovejoy also noted instances of termination and demotions without due process (Pollitt \& Kurland, 1998). At the University of Colorado, a prominent law professor was dismissed for representing the miner's union despite the governor's and president's warnings against doing so (Pollitt \& Kurland, 1998). At Wesleyan University in Connecticut, a professor was fired for things he said that had no relation to a classroom or teaching setting, and had nothing to do with his specialty. Furthermore, he was not given a trial (Pollitt \& Kurland, 1998).

In a similar situation, Scott Nearing, a professor at the University of Pennsylvania, was not given a contract renewal due to off-campus statements. The Board of Trustees, as well as many large donors, rushed the decision without any formal process; refused to listen to hundreds of supportive students and faculty; and refused to give a reason for his termination (Pollitt \& Kurland, 1998; Brubacher \& Rudy, 1997). The university claimed that because "non-renewal" was not the same as dismissal, the decision did not involve academic freedom issues (Pollitt \& Kurland, 1998). 
In 1915, the AAUP released its first statement. In the statement, the AAUP said that in order for professors to perform their best in the classroom, they must have "assurances of an honorable and secure position" (Pollitt \& Kurland, 1998). The AAUP also noted that it wanted a faculty body to decide whether or not someone should be dismissed. The people determining who should be fired, they said, should not be the administration, but rather, part of the profession. The AAUP was calling for a trial in front of other faculty. A trial by one's peers was a major part of the AAUP's agenda and they were greatly opposed to anything else (Pollit \& Kurland, 1998).

As part of their 1915 statement, the AAUP wanted to tie tenure more closely to judicial procedure. Before a faculty dismissal, there would be a mandatory faculty trial. This right, however, only applied to the higher-ranking professors who already had tenure (Joughin, 1963). The right was not extended to lower level faculty because the AAUP still believed that someone should prove his or her merit before receiving such honorable rights (Metzger, 1973). All those who completed a fixed period of probation, however, should be given indefinite tenure (Pollitt \& Kurland, 1998).

The AAUP's next big statement was issued in 1925. Expanding on the 1915 proclamation, it promoted that the "accused teacher should always have an opportunity to face his accusers" (Metzger, 1973). At this point, faculty still had not yet received official power or job security. For example, a college or university could terminate, even tenured faculty, on a variety of grounds including financial "exigency" (Carvalho \& Downing, 2010).

Fifteen years later, the 1940 Statement of Principles on Academic Freedom and Tenure by the AAUP was released, becoming its most widely endorsed and influential paper. Tenure became defined as "(1) freedom of teaching and research and of extramural activities, and (2) a sufficient degree of economic security to make the profession attractive to men and women of ability" (AAUP, 2006). The document stated that all dismissals must be for adequate cause and that the Board of Trustees must almost always allow a faculty trial (AAUP, 2006). Prior to the trial, the Board must also present written charges against the professor.

While the AAUP was actively seeking to provide policies to protect professors, courts also moved in the direction of protecting professors. The courts decided that a state, as an employer of public universities, must give professors the right to be heard before dismissal (Van Alstyne, 1970). Effectively, the courts determined that professors who had proven themselves should have the same rights as citizens, including due process and right to a trial (AAUP, 2006).

The AAUP's Statement also cleared up confusion surrounding the probationary period prior to potentially receiving tenure. Tenure became more closely tied to years of service, helping to further diminish its reliance upon being connected to high-level administrators. This was accomplished by clarifying that faculty time at different colleges should count towards tenure, and redefining the probationary period to be a pre-tenure time period. This removed the idea that faculty at this level were just inexpensive, unhopeful labor (Metzger, 1973). Lower level faculty members, however, did not have the same trial rights as their tenured counterparts (Metzger, 1973).

\section{The Current State of Tenure in the United States}

Section two outlines an historical account of tenure that provides the necessary foundation to fully grasp the intricacies and nuances of the current tenure system. This section will focus on the practice of tenure in the United States in the beginning of the twenty-first century at institutions of higher education (both public and private) by examining four areas: 1) the process of gaining tenure; 2) post-tenure review systems; 3 ) the dismissal procedure for a tenured professor; and 4) the perspective of deans, administrators, and the community on tenure.

During this analysis, it is important to keep in mind the commonly held presumption that tenure guarantees a professors' lifetime employment after he or she has demonstrated significant contribution to the institution, usually in the areas of scholarly work and teaching (Garret, 2013). A presumption also exists that tenure was created, in part, in response to what was considered unjustified dismissals of professors who expressed unpopular views (Pollit \& Kurland, 1998). While tenure at the University level is a widely adopted practice across the country, there are institutions that have opted out of its use, including Principia College, Florida Gulf Coast University, and Evergreen State College (Wilson, 2010).

While this section will admittedly make general statements about tenure and its procedures, there are often important nuances between large research institutions and small colleges. Tenure is most prominent at large research universities, while the practice appears to be in danger and is being slowly phased out at some of the smaller liberal arts colleges. For some university administrators, it is impossible to ignore the financial benefits that are realized as the percentage of tenured professors decreases in comparison to the increase of adjunct faculty (Wilson, 2010).

\subsection{The Process of Obtaining Tenure}

The process of gaining tenure is the most similar of the four aspects the authors will address amongst various universities across the United States. At universities, a timeline for tenure recognition is generally specified in an official university 
tenure policy (Loyola Marymount University (LMU), 2013; Santa Clara University, 2002; (University of California, Los Angeles (UCLA), 2008a; UCLA, 1998b). Across the nation, the process for gaining tenure at a private or public university generally happens in the sixth or seventh year of service as a professor (within the same university or others if previously agreed in the initial employment contract). Once the sixth or seventh year of service is reached, the professor is required to submit an involved application for tenure consideration (LMU, 2013; Santa Clara University, 2002; UCLA, 2008a).

Each institution has its own unique requirements and considerations of what makes an individual worthy of tenure. These requirements generally align with the institution's mission as a whole (Bannister, 2010) and follow the holy grail of teaching, research, and service. Some institutions add their additional criteria, while others remain faithful to the holy trinity (American Council on Education, AAUP, and United Educators Insurance Risk Retention Group, 2000). For example, Jesuit Universities, such as Santa Clara and LMU have a focus on social justice and note that service to the university beyond academics is of consideration during tenure review (Santa Clara University, 2002; LMU, 2013). In contrast, UCLA, a renowned research institution, stresses the importance of the candidate's research and teaching contributions, over service in consideration for tenure (UCLA, 2008a).

At LMU, a professor can apply for tenure consideration after his sixth year of teaching (LMU, 2013). Similar to LMU, the University of California system considers professors' applications for tenure after six years of service. UCLA has a policy of an "eight year clock"- if a professor is not granted tenure by his or her eighth year of service, he or she will be asked to leave the university (UCLA, 1998b). The concept of using a tenure clock, similar to the "up or out" mentality of many large corporations, is still prevalent in tenure policies at higher education institutions across the country, including, but not limited to, University of Colorado Boulder and the University of Michigan (University of Colorado, 2014; University of Michigan, 2014). The tide, however, may be shifting towards modifying this practice, largely because it does not account for circumstances such as having a child or caring for an ill family member, which may require pre-tenured faculty to take leave from their position for a period of time (Bannister, 2010; UCLA 1998b).

Eight years is characteristic of most tenure clocks, but these "clocks" do vary among universities. For example, the University of Idaho has one of the shortest timelines for tenure recognition; the University specifies year four as the beginning of tenure consideration and also has a shorter tenure clock of only six years (University of Idaho, 2014). The University of Michigan, in contrast, has extended its tenure clock to ten years to accommodate life choices (University of Michigan, 2014). Generally, though, from the above referenced examples, we see two patterns: 1) a professor is not typically encouraged to apply for tenure before the sixth or seventh year of service and 2) a professor is generally expected to gain tenure by the eighth year.

\subsection{Post Tenure Review Systems}

New to the tenure system in the last decade is the prevalence of post-tenure review. Post-tenure review is any system of evaluation or performance review of tenured faculty members outside of traditional evaluation procedures for all professors. The frequency and methods of these reviews vary across the country (Association of American Universities (AAU), 2001). During the early introduction of post tenure review, the AAUP fought hard against the practice, stating that the practice demeans the fundamental purpose of tenure (AAU, 2001). The AAUP did not prevail and has given up trying to stop this trend because it has become so commonplace. Now, the AAUP is making strong attempts to shape the post-tenure review processes in favor of the tenured professor. The AAUP advocates for developmental programs for tenured professors who are not adequately performing rather than termination (AAU, 2001).

According to the AAU's Post-Tenure Review document, the focus of post-tenure review amongst the participating universities is toward faculty development and accountability. These systems are designed to reward strong performance and address insufficient performance. Peer review committees and/or the department chair conduct the post tenure review (AAU, 2001). Some post-tenure review programs do involve developmental programs like the ones advocated by the AAUP, while others are solely consequence/reward outcome based (AAU, 2001). Post-tenure review systems are more widely implemented at public universities than at private universities. This is most likely due to the influence that state legislators and governing bodies have on public higher education institutions (AAU, 2001).

What is surprising about post-tenure review is the favorable faculty support of these systems. Faculty members of the AAUP report that post-tenure review policies have led to deserved recognition for exceptional performance and do allow for earlier correction of unsatisfactory performance (AAU, 2001). One barrier to implementing post-tenure review systems is the financial burden it places on the institution. Institutions without these systems have cited that the cost benefit analysis does not warrant implementation (AAU, 2001).

\subsection{The Dismissal Procedure for a Tenured Professor}

Universities have procedural protection for the dismissal of tenured professors. The professor will receive a notice 
explaining the reasons for dismissal. Typical of institutions across the United States, charges against tenured professors may only be formally brought by the university. Once a formal notice of charges has been sent to the tenured professor, he or she will then have the opportunity to respond to the charges. The charges usually undergo peer evaluation, as well as further administrative investigation (Matheson, 1975). Dismissal procedures for tenured professors involve many faculty members' opinions (Matheson, 1975). Thus, a tenured professor can rarely, if ever, get fired because the institution's administration or dean simply does not like him or her. The involved dismissal procedures provide a safeguard for tenured professors simply because of the lengthy and difficult termination process (Matheson, 1975).

For example, the dismissal process for a tenured professor in the University of California system is lengthy, expensive, and very involved. Only the regents of the university can terminate a tenured professor's employment in the University of California system, which can only take place after review by a campus faculty committee, the campus chancellor, and the system president. This is a drawn-out and intricate process that has only resulted in a few dozen tenured professors being fired in the last two decades (Gordon, 2012). Considering that the UC system employs some 10,886 tenured faculty, the number of tenured faculty terminations is proportionally very small (Asimov, 2011; Gordon, 2012).

\subsection{The Perspective of Deans, Administrators, and the Community on Tenure}

In a recent survey conducted by the Pew Research Center in association with The Chronicle, sixty-nine percent of university leaders would prefer that a majority of faculty work under long-term contracts instead of tenure (Stripling, 2011). Presidents of private four-year institutions express less enthusiasm about tenure than their counterparts at public universities. Forty percent of private institution presidents prefer to work with and hire faculty with long term contracts, as opposed to thirty percent who favor tenure. Their public counterparts voiced greater support for tenure, with fifty percent of leaders preferring to work with and hire tenured faculty over long term contract faculty (Stripling, 2011). To break these statistics down even further, we see that in public institutions, fifty-two percent of leaders who were previously faculty, favored tenure, while only thirty-seven percent without professor experience were in favor of tenure. Private institutions show the same pattern in smaller numbers: Thirty-five percent of institution leaders with faculty experience favored tenure while only twenty percent of those without the experience were in favor of tenure (Stripling, 2011). This data demonstrates that most university leaders today prefer faculty to have long-term contracts instead of tenure. The two main reasons are that tenure protections make it challenging to dismiss incompetent faculty and that the system fosters a culture of complacency. These two outcomes of the current tenure system are referenced as issues that do not allow leaders of both private and public higher institutions to realize their goals of excellence for the institution (Stripling, 2011).

\section{Alternative Options for Tenure Reform}

In response to changing notions regarding tenure in higher education, various options will be explored to promote a necessary, nuanced, and civil discussion on the current state and future of the tenure system. The following five options will be examined: (1) retain the current tenure system; (2) abolish the system; (3) require tenure renewal after a specified time period based on minimum standards; (4) grant tenure for a specified time period, after which, the professor must reapply for tenure; or (5) create a system of regional tenure committees to grant master tenure status which transcends that of individual institutional tenure.

\subsection{Retain the Current Tenure System}

Option one is to continue using the current tenure system, which includes the granting, post-tenure review, and dismissal processes described in section three of this paper. According to the AAUP, the primary purpose of tenure is to enforce a professor's contractual right to not have his or her position terminated without just cause. This allows professors to challenge student and administrative thinking, as well as conventional wisdom (Clawson, 2009; Ruben, 2002). Proponents of the current tenure system further argue that it enables the thorough development of new ideas, perhaps even over the course of several decades. Scholarly breakthroughs and patterns in research take extensive time to be discovered. The current system allows professors to venture into uncharted territories in the classroom, article publications, and express controversial ideas in public arenas (Clawson, 2009; Wilson, 2010). This benefits not only students, but also society at large.

Proponents of the current system also argue that it allows professors to perform better because they are unencumbered by the anxiety or fear of being dismissed. This sense of security and freedom of expression outside the classroom opens the door for them to focus on teaching and doing research at the highest level, due to the lack of distraction that job insecurity creates. Furthermore, the current tenure system creates a strong loyalty to the university. This fosters a collaborative team of tenured professors who are personally and professionally vested in the best interest of the university, due to lifelong mutual commitment with the institution. Lastly, the promise of a secure and stable job attracts qualified people to pursue the profession. Therefore, by keeping the current tenure system strong, universities will continue to have a steady supply of professors (Palmer, 2012; Riley \& Nelson, 2012). 


\subsection{Abolish the System}

An opposing tide asserts the second option: that the current tenure system must be completely eliminated. The foremost reason cited for completely abolishing tenure is that it would create an environment of healthy competition that would motivate high performance and productivity (Palmer, 2012). Professors would be expected to maintain a high level of performance to keep their jobs, similar to those who hold the vast majority of high level jobs in the United States. Eliminating tenure would also be a cost-effective move for universities because they could hire less expensive, and potentially more innovative younger professors. Universities would have the freedom to bring in new blood to engage students with current teaching methodologies and cutting edge research. Opponents of tenure also assert that the tenure system does not allow universities to adapt to the changes in demand for education in certain fields as quickly. If these universities were not committed to paying high salaries to professors in fields of low student interest and participation, these universities could easily allocate funds to hire professors to teach in areas of increased relevance to students' needs. Furthermore, universities could spend more money supporting exceptional teaching instead of funding questionable research and publication that is the key component of the tenure process (Wetherbe, 2013; Beam, 2010; Riley \& Nelson, 2012).

\subsection{Require Tenure Renewal after a Specified Time Period Based on Minimum Standards}

The third option, less extreme than complete elimination, modifies the current system to require tenure renewal after a specified time period based on minimum standards. Active renewal every few years reminds the professor of his or her commitment to fulfilling the excellence required of a tenured professor. Minimum requirements would be specified based on the mission of each university, and likely include research and publication, service, and teaching evaluation benchmarks. This renewal system is more involved than current post-tenure review systems due to its underlying premise. The term renew means to restore to existence (Merriam-Webster, 2015). This indicates that the original state ceases to exist, in order for the renewal process to restore its existence. In this renewal system model, there is just enough uncertainty about future employment to motivate continual high performance. An environment of insecurity has been infused with hope. It becomes an environment of manageable insecurity because it has the purpose of restoring existence, rather than stripping it. Moreover, the renewal process would mirror the renewal of license requirements to practice as an attorney, CPA, or doctor. Even judges in many states must provide evidence of keeping current in one's profession to retain their elected positions. Many advocates of this option do not understand why tenured professors should be exempt from providing evidence of meeting continuing standards of academic performance (Seeborg \& Olson, 2011).

Although the nature of this renewal system is to restore existence, it does leave the door open to the possibility of not restoring existence, thus providing a path for the dismissal of underperforming professors. Because the tenure renewal process is based on specific guidelines, it creates a strong framework to justify non-renewal. This renewal system will flush out poorly performing professors in a fair and efficient manner, and allow for the hiring of eager and highly competent professors. This could alleviate the concern about generational gaps with professors that may be due to the economic recession when universities are hiring at lower rates. If underperforming, highly paid professors are dismissed more efficiently, which this renewal process facilitates, there will be available funding for the new generation of younger professors.

\subsection{Grant Tenure for a Specified Time Period, After Which, the Professor Must Reapply for Tenure}

Along similar lines, the fourth option alters the system by only granting tenure for a specified time period, such as seven or eight years. After this specified time period, the professor's tenure will expire and he/she will be required to reapply for tenure. This reform attempts to address the culture of complacency and the difficulty in firing tenured professors. Instead of going through a lengthy and expensive firing process, a university can instead not grant tenure to the candidate subsequent to his or her first period of tenure. The consistently looming tenure expiration date will incentivize professors to produce evidence that proves they deserve to be re-granted tenure at such a date.

\subsection{Create a System of Regional Tenure Committees to Grant Master Tenure Status, Which Transcends That of Individual Institutional Tenure}

The final option presented proposes the creation of an objective regional tenure committee that would grant Master Tenure status. Once a professor has achieved institutional tenure, he or she can strive toward Master Tenure status. This ultracompetitive distinction will be granted on the basis of exemplary teaching, research and publication, as well as contributions to the academic community. The status will allow for mobility between universities, as Master Tenure would be recognized among groups of regional universities. Master Tenure will give necessary recognition to deserving professors who excel in their profession in their post-tenure years. An independent regional committee will evaluate standout professors from each university against the finest professors across the region. The designation of Master Tenure will urge professors to continue to grow in the latter years of their careers and strive for further excellence. This option aims to resolve the most persistent issue in the current tenure system, which is the culture of complacency that is created 
by the shield of a permanent job security and the lack of incentives to achieve greater excellence, by increasing recognition of deserving professors and providing career mobility between universities.

Moreover, Master Tenure status may help to address an additional problem of tenure rarely discussed. Due to the lengthy tenure process and the desire for tenure, Ph.D.'s are justly motivated to begin the tenure track as quickly as possible. More often than not, they will join the tenure track at the first university where they are hired, thus shaping their perspectives into the cultural expectations of a single institution. Since the current tenure system encourages lifelong employment at one institution, it limits the diversity of creative thinking at each institution of higher education that could be opened through the cross pollination of bringing star professors from other institutions. Institutions will be more effective if they have seasoned professors from other institutions that bring with them diversity in knowledge, experience, methodology, and more.

Under the last option, professors with exceptional performance will be granted Master Tenure. This will foster competition among universities to attract the best professors. Since members of each conference will be aware of outstanding performance, and tenure will be applicable throughout the conference, a university looking to strengthen certain departments will have the opportunity to hire Master Tenure professors. It follows that this system benefits professors with salary increases and career mobility, as well as the privilege of working with a diverse group of colleagues. Having a blend of master-tenured professors at each university will enhance the creativity and drive of the other professors. The best practices of each university will be brought together to create a vibrant community of scholars, improving professor productivity, and giving students a more effective learning experience. The creation of a regional Master Tenure granting committee has the ability to rejuvenate an antiquated system by instilling it with the proven success of competition, accountability, incentives and diversity.

\subsection{Next Steps}

A possible method of reviewing the five distinct options mentioned above in relation to an individual university or college is to determine the most important stakeholder (Bohlman \& Dundas, 1996a). The first step is to list the stakeholders of the institution such as the non-tenured professors, tenured professors, university administrators (deans), students and the general community. The next step is to select the most important stakeholder from the identified groups. In order to rank the importance of the stakeholders identified we must first analyze the values of the modern day university generally expressed in the institution's mission statement. LMU's mission, "The encouragement of learning, the education of the whole person, the service of faith and the promotion of justice," points to the students as the most important stakeholder (LMU Mission Statement, 2015; Bohlman \& Dundas, 1999a). Neighboring UCLA's mission statement, "UCLA's primary purpose as a public research university is the creation, dissemination, preservation, and application of knowledge for the betterment of our global society," indicates that the community is its most important stakeholder (UCLA, 2015c; Bohlman \& Dundas, 2001b). Decisions regarding the future of the tenure system should uphold values that support a university's most important stakeholders as identified through its mission statement.

A further step is to list the five aforementioned options with respect to tenure and other additional options that may be developed to determine which of these tenure options would best support the selected stakeholder (Bohlman \& Dundas, 2001b).

This seemingly simple process is certainly not easy and will not provide a silver bullet, but it will help to create a serious conversation about the future of tenure.

\section{Conclusion}

For those of us with tenure, we do remember the hard journey filled with years of work often mixed with careful awareness of the political climate of the institution and its functionaries until reaching the prize of being granted tenure. After this achievement and the privileges provided, it is difficult to envision changing the system. After all, if we went through this gantlet, should not others be forced to endure the same passage? Additionally, if change were implemented, would it not put our accomplishment and advantages at risk?

For the proponents of tenure, tenure is necessary to protect the professor's freedom to conduct controversial research. They argue that tenure is also necessary to shield a professor's association or sharing of ideas that are contrary to society's opinions or the powers that be. Moreover, tenure proponents assert that since the number of Ph.D.'s significantly outweighs the number of tenure tracked positions in the United States, universities have their choice and will only hire those individuals who are excellent teachers and researchers in their respective fields. Proponents argue that if universities make good hiring decisions then tenure is not an issue because these professors will continue to remain relevant and current in their teaching and research. The tenure system, they also argue, does not encourage conformity because curriculums at universities continually change (Riley \& Nelson, 2012).

In sharp contrast, opponents of tenure argue that because tenure rewards research over teaching, professors spend more 
time researching and writing than time actually teaching their students. They argue that adjunct professors, who are non-tenured tracked, are doing most of the teaching (Riley \& Nelson, 2012). Currently, over seventy-six percent of faculty across all higher education institutions including liberal arts colleges, research colleges, research universities, and community colleges are adjuncts (Segran, 2014).

Classes largely taught by adjuncts may lead to lower graduation rates for students and grade inflation (Riley \& Nelson, 2012). Opponents find that the best way to improve the quality of education for students is to abolish tenure. They argue professors should be evaluated for their teaching ability without guarantees that they will continue to be employed even if their teaching skills do not measure up. Opponents also attack the concept that tenure is needed to maintain academic freedom. They argue that tenured professors only promote and give tenure to those who think like them. Individuals, who define academic freedom, by disagreeing with the conventional wisdom, are never given tenure (Riley \& Nelson). Moreover, opponents argue that when universities award tenure, they take a serious gamble that a newly tenured professor's research is going to be just as relevant years from now, as it is today (Beam, 2010).

This article's review of the history of tenure and its current state suggests that America's university tenure system requires a change. Clearly, there are important arguments to be made on both sides of the issue. Accordingly, the change to the tenure system must reflect the concerns of both proponents and opponents of tenure and have the mission of each university at its core. This will enable tenure to further enhance the scholarly direction of our country, and our leadership in the world.

Machiavelli wrote in The Prince (1532), "There is nothing more difficult to take in hand, more perilous to conduct, or more uncertain of its success, then to take the lead in the introduction of a new order of things" (Machiavelli, 1532). There are many powerful forces that will defend the status quo, especially those of us with tenure and those of us who are seeking the protection of tenure. And yet, most of us have experienced its abuses in colleagues and even in ourselves. Ecclesiastes reminds us that there "is a time to keep and a time to discard" as well as "a time to tear down and a time to build up" (Ecclesiastes 3:3). This is a time to assess the current goals of tenure and review possible alternatives.

\section{References}

American Association of University Professors, (2006). 1940 Statement of Principles on Academic Freedom and Tenure, 3. http://www.aaup.org/report/1940-statement-principles-academic-freedom-and-tenure.

American Council on Education, American Association of University Professors, and United Educators Insurance Risk Retention Group, (2000). Good Practice in Tenure Evaluation, 5.

http://webcache.googleusercontent.com/search?q=cache:pRjjuBGW7QAJ:www.aaup.org/sites/default/files/files/G ood\%2520Practice\% 2520in\%2520Tenure\%2520Evaluation.pdf+\&cd=1\&hl=en\&ct=clnk\&gl=us.

Association of American Universities, (2001). Post-Tenure Review, 1-10. https://www.aau.edu/WorkArea/DownloadAsset.aspx?id=470.

Asimov, N., (2011). Colleges Replace Tenured Professors with Lecturers. San Francisco Chronicle, 2. http://www.davisenterprise.com/local-news/colleges-replace-tenured-professors-with-lecturers/

Baldwin, E. (1841). History of Yale College: From its Foundation, AD 1700, to the year 1838 (61st ed., 364) New Haven, Ct: B. \& W. Noyes.

Bannister, L. (2010). President's Task Force on Rank and Tenure, 8-9, 19. http://www.lmu.edu/Assets/Academic\%20Affairs\%20Division/Faculty\%20Senate/President $\$ ! 27 \mathrm{~s} \% 20 \mathrm{Task} \% 20$ For ce\%20on\%20Rank\%20\$!26\%20Tenure\%20Final\%20Report.pdf.

Beam, C. (2010). Finishing School: The Case for Getting Rid of Tenure. slate.com, 1-3. Retrieved from http://www.slate.com/articles/news_and_politics/politics/2010/08/finishing_school.html

Bohlman, H., \& Dundas, M. (1999a). The Legal Ethical and International Environment of Business (4th ed.). Cincinnati, Ohio: West.

Bohlman, H., \& Dundas, M. (2001b). Revised Ethics Decision Model. The Legal Ethical and International Environment of Business (5th ed.). Cincinnati, Ohio: West.

Brown, R., \& Kurland, J. (1990). Academic Tenure and Academic Freedom, Faculty Scholarship Series, Paper 2718, 325-354. Retrieved from http://digitalcommons.law.yale.edu/fss_papers/2718.

Brown, W. (1997). University Governance \& Academic Tenure: A Property Rights Explanation. Journal of Institutional and Theoretical Economics (JITE), 3(153), 441-459.

Brubacher, J., \& Rudy, W. (1997). Higher education in Transition: A History of American Colleges and Universities, $1636-1968$ ( $4^{\text {th }}$ ed $)$. U. S. A: Transaction. 
Cameron, M. (2010). Faculty tenure in academe: The Evolution, Benefits and Implications of an Important Tradition. Journal of Student Affairs at New York University VI. Retrieved from http://steinhardt.nyu.edu/scmsAdmin/media/users/lh62/CameronJoSA_.pdf.

Carvalho, E., \& Downing, D. (2010). Academic Freedom in the Post-9/11 Era, 6. New York: Palgrave Macmillan.

Clawson, D. (May 29, 2009). Tenure and the Future of the University, 324 SCIENCE 1147. Retrieved from http://www.sciencemag.org/content/324/5931/1147.short .

DeVol v Board of Regents of University of Arizona. (1899), 56 P. 737, 738.

Dowley, T. (1989). Introduction to the History of Christianity, 246. Minneapolis: Fortress Press. Ecclesiastes 3:3. (1989). The Holy Bible: Containing the Old and New Testaments with the Apocryphal/Deuterocanonical books: New Revised Standard Version. New York: Oxford University Press.

Flood, J. (2012). Judicial Influence on Academic Decision-Making: A Study of Tenure Denial Litigation Cases in Which Higher Education Institutions did not Wholly Prevail. PhD diss., University of Tennessee, 74-75. http://trace.tennessee.edu/cgi/viewcontent.cgi?article=2552\&context=utk_graddiss.

Garret, R. (July 24, 2013). What is Teacher Tenure? Education.com, 1.

Gordon, L. (January 16, 2012). Tenured UC Riverside Professor Faces Rare Firing Discussions. Los Angeles Times, (p. 1). Retrieved from http://articles.latimes.com/print/2012/jan/16/local/la-me-uc-prof-20120116

Gillian v. Board of Regents of Normal Schools (1894). 88 Wis. Sup. Ct. R. 7, 12.

Jeffrey, D., \& Manganiello, D. (1998). Rethinking the Future of the University (p. 13). Ottawa: University of Ottawa Press.

Joughin, L. (1963). Academic Due Process, Law and Contemporary Problems, 573-574. http://dx.doi.org/10.2307/1190645

Loyola Marymount University. (2013). Faculty Handbook and Handbook Addenda, 9. http://academics.Imu.edu/media/Imuacademics/ranktenure/documentsandpdfs/LMU\%20Faculty\%20Handbook_20 14-15.pdf.

Machiavelli (1532). The Prince, 6.

Matheson, A. (1975). Judicial Enforcement of Academic Tenure: An Examination. Washington Law Review, 50, 597622.

McCormick, R. (1988). “The Natural Law: Recent Literature." Dissent in the Church. No. 7: Natural Law and Theology, 173-183, by Charles E. Curran and Richard A. McCormick, S.J. (Eds.). Mahwah: Paulist Press, 1991.

McNair, G. (1898). The Relations of the Students and Citizens at Paris, Madison 1200-1350. USA: University of Wisconsin, Madison.

Metzger, W. (1973). Academic Tenure in America: A Historical Essay. Faculty Tenure: A Report and Recommendations by the Commission on Academic Tenure in Higher Education, 95, 101-102, 105, 107-108, 116, 123, 126, 128-130, 134, 137, 139, 149, 151-153. San Francisco: Jossey-Bass.

Mohr, J. (1970). Academic Turmoil and Public Opinion: The Ross Case at Stanford. Pacific Historical Review, 1(39), 39-60. http://dx.doi.org/10.2307/3638197.

Palmer, C. (November 16, 2012). Essay Urges Academe to Rethink Tenure. Inside Higher Ed, 2, 3. Retrieved from https://www.insidehighered.com/advice/2012/11/16/essay-urges-academe-rethink-tenure

Peirce, B. (1833). A History of Harvard University From its Foundation, in the Year 1636, to the Period of the American Revolution, 140. Cambridge: Brown, Shattuck. Retrieved from https://archive.org/stream/historyofharvard00peiruoft\#page/n9/mode/2up.

People Ex Rel Kelsey v. New York Medical School, (1898), 29 App. Div. 244, 248.

Peterson, M. (2007). Academic Tenure and Higher Education in the United States: Implications for the Dental Education Workforce in the Twenty-First Century. Journal of Dental Education, 71(3), 355-355. Retrieved from http://www.jdentaled.org/content/71/3/354.full.pdf+html.

Pollitt, D., \& Kurland, J. (1998). Entering the Academic Freedom Arena Running: The AAUP's First Year. In ACADEME 4(84) 45-52. http://dx.doi.org/10.2307/40252312

Quincy, J. (1840). The History of Harvard University, 36. Cambridge Mass: J. Owen. 
Riley, N., \& Nelson, C. (2012). Should Tenure for College Professors be Abolished? Wall Street Journal, 1, 2-3, 4-6. Retrieved from http://online.wsj.com/news/articles/SB10001424052702303610504577418293114042070

Ruben, D. (2002). Tenure: Perspectives and Challenges, 1, 3. Retrieved from http://www.aaup.org/issues/tenure/tenure-perspectives-and-challenges-2002

Santa Clara University (April 2002). Santa Clara Faculty Handbook, 3.4.1. Retrieved from http://www.scu.edu/cas/facultyandstaff/upload/facultyhandbook.pdf.

Schuster, J., \& Finkelstein, M. (2006). The American Faculty: The Restructuring of Academic Work and Careers, (p. 426). Baltimore: Johns Hopkins University Press.

Seeborg, M., \& Olson, G. (2011). Post-Tenure Review System That is Good Personal Policy: It is Possible. International Business and Economics Research Journal, 1(5), 7. http://www.cluteinstitute.com/ojs/index.php/IBER/article/viewFile/3919/3964.

Segran, E. (April 28, 2014). The Adjunct Revolt: How Poor Professors are Fighting Back. The Atlantic, 2. Retrieved from http://www.theatlantic.com/business/archive/2014/04/the-adjunct-professor-crisis/361336/.

Siow, A. (1998). Tenure and Other Unusual Personnel Practices in Academia. Journal of Law, Economics and Organization, 14(1), 156-57, 167-68. http://dx.doi.org/10.1093/oxfordjournals.jleo.a023395

Stripling, J. (May 15, 2011). Most Presidents Prefer no Tenure for Majority of Faculty. The Chronicle of Higher Education, 1-6. Retrieved from http://chronicle.com/article/Most-Presidents-Favor-No/127526/.

Unger, H. (2007). Encyclopedia of American Education, 1114. ( $3^{\text {rd }}$ ed.).

University of California, Los Angeles. (June 13, 2008a). Academic Personnel Manual, Appendix 6: Appointment and Advancement of Assistant Professors at UCLA, 1-2.

https://www.apo.ucla.edu/policies/the-call/appendices-1/appendix-6-appointment-and-advancement-of-assistant-pr ofessors-at-ucla.

University of California, Los Angeles, (September 1998b). Counting on the Tenure Clock (2). Retrieved from https://www.apo.ucla.edu/resources/trifolds/counting-on-the-tenure-clock.

University of California, Los Angeles (2015c). Mission Statement. Retrieved from http://www.ucla.edu/about/mission-and-values.

University of Colorado (2014). The Tenure Clock. Retrieved from https://facultyaffairs.colorado.edu/faculty/reappointment-promotion-and-tenure/related-policy-information/the-tenu re-clock.

University of Idaho (January 14, 2014). Faculty/Staff Handbook, F-1. Retrieved from http://www.webpages.uidaho.edu/fsh/3520.html.

University of Michigan, (2014). The University of Michigan Faculty Handbook, 6.C, Retrieved from http://www.provost.umich.edu/faculty/handbook/6/6.C.html.

Van Alstyne, W. (1970). The Constitutional Rights of Teachers and Professors. Duke Law Journal, 1970(5), 860. http://dx.doi.org/10.2307/1371681.

Webster, M. (2015). Dictionary. merriam.webster.com, 1. Retrieved from http://www.merriam-webster.com/dictionary/renew.

Wetherbe, J. (March 13, 2013). It's Time for Tenure to Lose Tenure. Harvard Business Review, 2-3. Retrieved from https://hbr.org/2013/03/its-time-for-tenure-to-lose-te/.

Wilson, R. (July 4, 2010). Tenure, RIP: What the Vanishing Status Means for the Future of Education. The Chronicle of Higher Education, 1-4. Retrieved from http://chronicle.com/article/Tenure-RIP/66114.

Wiseman, N. (1898). Part 2. In The Dublin Review, 87. The Tablet Publishing Company.

White, L. (2007). Academic Tenure: It's Historical and Legal Meanings in the United States and its Relationship to the Compensation of Medical School Faculty Members. Saint Louis University Law Journal, 51, 63.

\section{(cc) $\mathrm{BY}$}

This work is licensed under a Creative Commons Attribution 3.0 License. 